\title{
THE WATER POLLUTION RESEARCH LABORATORY
}

$\mathrm{T}$ HE Water Pollution Research Laboratory of the Department of Scientific and Industrial Research held open days on May 6 and 7. This organization was formed in 1927, but the Laboratory at Stevenage was not occupied until October 1954. The total staff, which includes chemists, chemical engineers, physicists and biologists, is at present about 120 . The Station carries out small-scale and pilot-scale work and also has facilities for work with large plant built in the open, particularly on the treatment of sewage, which can be pumped from a domestic sewer crossing the site. It was stated that an additional wing, containing further pilot-scale laboratories, is being designed and that it will probably be built in 1960

The field of work of the Station is in the improvement and development of methods of treating sewage and industrial effluents, and in the study of the effects of pollution on surface waters, including rivers and estuaries. Of the work on sewage, part is of an empirical kind and part more fundamental. In the first category, for example, the Laboratory is comparing the efficiency of different types and size of medium in percolating filters, of which there is a large experimental installation in the grounds. The more fundamental work on sewage includes a detailed study, mostly with pilot plant, of the mechanism and efficiency of aeration in the activated-sludge process, of the factors affecting the drying of sewage sludges, and of the effect of household detergents on sewage treatment. Apart from the obvious effects of these materials - that is, the occurrence of foam, often some feet deep, at sewage works-they have caused a marked deterioration in the biological processes of treatment at some works, particularly at those which use the activated-sludge process, in which sewage is aerated either mechanically or by diffused air in contact with an active bacterial floc. Work at Stevenage has shown that the immediate effect of detergents is to reduce the rate of transfer of oxygen from bubbles of air to the liquid, and that in those plants where initially the rate of aeration was sufficient only to maintain a comparatively small concentration of oxygen in solution, the further inhibition of oxygen transfer has been responsible for the deterioration observed. It was announced recently that manufacturers of detergents were trying to develop surface-active materials which would be more easily decomposed by bacterial action than those at present in use, and in one experimental plant at the Laboratory some of the more promising compounds were being tested by treating them, in admixture with domestic sewage, in small activated-sludge plants. In these tests the conditions of operation are controlled; for example, the liquid is aerated with mixtures of air and nitrogen to maintain a desired constant concentration of oxygen in solution. Some of the materials submitted for test are much more readily decomposed during sewage treatment than are those at present on the market.

A substantial effort is directed to the improvement of methods of treating industrial waste waters, and in this work the Laboratory is closely associated with the Federation of British Industries. One investi- gation now nearing completion has dealt with the anaerobic digestion of certain industrial liquors-for example, those from slaughter-houses-containing high concentrations of organic matter. For suitable liquids this process may well be economic-for example, with slaughter-house waste more than 90 per cent of organic carbon is converted to methane and carbon dioxide during a period of treatment of $24 \mathrm{hr}$. -and the process is likely to go into full-scale use in Britain in the near future. A plant was also shown in which tannery wastes, which often contain sodium sulphide used for removing hair from hides, is treated with flue gas to neutralize it, the hydrogen sulphide in the flue gas being oxidized to sulphuric acid by biological action in a percolating filter. Apart from these long-term projects the Laboratory acts as an advisory service to industry and frequently undertakes short investigations for particular firms on a repayment basis.

One important aspect of the work of the Laboratory is the study of the effects of polluting substances in surface waters. For some years the chief object of this study has been the Thames Estuary, the central reaches of which in dry weather are anaerobic, and where in consequence sulphate is reduced to sulphide by bacterial action. This survey, the final report on which has not yet been published but is in preparation, has involved much experimental work-for example, determinations of rates of oxidation of organic materials at different temperatures, and the study of the conditions in which ammonia is oxidized or nitrate is reduced by bacterial action-the results of which are applicable to the far simpler system of a fresh-water stream. In the Thames Estuary the most important effect of pollution of all kinds is to reduce the concentration of oxygen in solution in the water, since it is only when this has fallen to zero (and when any nitrate present has been reduced to nitrogen) that evolution of hydrogen sulphide occurs. In fresh-water streams many other effects of polluting substances may be important, particularly if the stream is expected to support a fishery or if the water is used for a public supply, but the lowering of the concentration of dissolved oxygen which results from the discharge of any oxidizable material is still one of the most objectionable results of pollution, and the level of oxygen is often taken as diagnostic of the general quality of the water.

In rivers which contain fish, oxygen tension is particularly important, not only because a certain mini mum level is necessary to support fish life, but also because a reduetion in tension increases the toxicity of any poisons which may be present. The Laboratory is studying the various factors which govern the oxygen balance of streams, in the hope of being able to reduce the margin of error with which the oxygen profile below the point of discharge of a given effluent to a given river can be predicted, and has already made some progress in this direction. The work has been greatly facilitated by the development of a robust recorder of the dropping-mercury type which can be used to give a continuous record of the level of dissolved oxygen in a river. The programme involves a knowledge of the rate of oxidation of 
polluting substances, of the rate at which the water of a stream will absorb oxygen from the air, and of the effects of aquatic plants and animals on the oxygen balance.

In the field, the only satisfactory method at present available for determining the rate of transfer of oxygen from the air is to reduce the oxygen tension in the water (by adding sulphite and a catalyst), following then the rise in level of oxygen below this point. This method has been used successfully for small streams, but presents obvious difficulties in a large river. Many of the factors involved, however-for example, turbulence, and the presence of substances such as detergents in solution which reduce the rate of oxygen transfer-are being investigated by running water through sloping troughs, $100 \mathrm{ft}$. long, in the grounds of the Laboratory. One question which is often important in Britain-namely, the change in oxygen-level in water when it flows over weirs-has been substantially settled by work in the field and in pilot-scale plant ; given the height from which the water falls, and the temperature, the extent to which the oxygen deficit is reduced can be predicted within narrow limits.

In rivers, oxidation and reduction of compounds of nitrogen often play an important part. Oxidation of ammonia and reduction of nitrate, and particularly the effect of concentration of dissolved oxygen on these processes, are being studied in an artificial river in which water passes through a series of tanks fitted with stirrers. In streams containing large numbers of algae or much rooted vegetation, the effects of the bacterial oxidation of polluting matter on oxygen tension may be greatly outweighed by photosynthetic production of oxygen and its consumption by plant respiration. These effects are being studied in a stream near the Laboratory, where continuous recorders are installed. In June and September 1958 there was a net release of $3.8 \mathrm{gm}$. oxygen $/ \mathrm{m} .{ }^{2}$ / day. Estimates are being made of the productivity of different reaches in this stream using cropping techniques assisted by aerial photographs taken by a camera suspended from a meteorological balloon. Consumption of oxygen by respiration of invertebrates is also significant, and this is being determined in respirometers in which the change in oxygen tension is again recorded continuously.

The Laboratory has a small but well-equipped Microbiological Section in which three main lines of work are in progress. The first is a detailed study of the changes which occur when aqueous solutions of organic compounds (which may be radioactively labelled) are passed over an active microbial film of the type which occurs in percolating filters and on which the purification of sewage by this process depends. The film is built up on the inside of a 'Perspex' cylinder, the long axis of which is inclined and about which it is rotated; the atmosphere in contact with the film is circulated and there are arrangements for withdrawing samples from it and for adding oxygen to replace that used in oxidation. Most of the organic substances present in such materials as sewage are very rapidly oxidized; one object of the work is to identify those which are not.

It is very important, in treating polluting liquids by biological processes, to be able, in the last stage of the process, to remove by sedimentation organic sludge from the liquid-the latter representing, of course, the final effluent from the plant. A large part of the organic matter to be removed consists of bacteria and the quality of the final effluent depends very largely on whether they will or will not agglutinate in the final sedimentation tank. In spite of a good deal of work on the subject, not much is known of the factors which affect flocculation in a treatment plant; these are therefore being studied by the section, using cultures isolated from sewage and sewage effluents.

The third line of work which is being pursued in collaboration with the National Coal Board is on the bacterial treatment of waste waters from coke ovens, in which the chief constituents to be removed are phenols, thiocyanate and ammonia. Rates of assimilation and oxidation of these substances are being studied in continuous-culture apparatus after preliminary trials by the usual Warburg technique.

The Microbiological Section has recently been strengthened by the transfer to it of some of the staff formerly working at the National Chemical Laboratory.

\section{WATER SUPPLY AND DEMAND IN GREAT BRITAIN}

$\mathrm{T}$ THE problem of water supply and demand, the need for improved hydrological knowledge and the necessity for a continuing study of the changing situation in Britain, have received editorial notice in earlier issues of Nature $(172,823 ; 1953$, and 176 , 1133 ; 1955). The decision to suspend the Inland Water Survey and disband the Central Advisory Water Committee during the economy measures of 1952 was, from a purely scientific point of view, strongly criticized. Happily this decision was reversed in 1955 when the Central Advisory Water Committee was reconstituted; and in the same year the Inland Water Survey also recommenced its labours and has since published a great deal of information covering the post-war years.

One of the first actions taken by the Central Advisory Water Committee in 1955 was to appoint two subcommittees to investigate information on water resources and the growing demand for water. Both these subcommittees have recently reported to the Central Committee and the information collected so far has now been published*.

Of the two documents, that of the Subcommittee on Information on Water Resources is perhaps the least controversial and may be considered first. This Subcommittee was appointed with the following terms of reference : (i) to review the current activities which contribute to our knowledge of the nation's water resources; (ii) to define the additional work needed to make a balanced survey of the quantity and quality of surface and underground water available for domestic, industrial and agricultural use; (iii) to advise on ways of collecting and interpreting * Central Advisory Water Committee. Subcommittee on The Growing Demand for Water-First Report. Pp. iv +28 . 18. 3d. net.
Report of the Subcommittee on Information on Water Resources. Report of the Subcommittee on Information on Water Resources.
Pp. ii +20 . 1s. $3 d$. net. (London: H.M. Stationery Office, 1959.) 